\title{
4. カメラ方式
}

\section{1. ま え がき}

家庭用テレビカメラは急激に固体撮像素子を採用し た製品へと移行している。この家庭用カメラには色フ イルタを画素毎に配置したカラー撮像用の固体撮像素 子が 1 つだけ使われた単板式カメラが使用されてい る.

単板式カメラは, 色フィル夕を用いて撮像信号を色 信号に多重し, この多重した色信号より複合カラー信 号を得るカラーカメラの構成方法である.このため, 色信号の多重化の方式が基本的なカメラ性能を決定す るので, 多重化方式には, 各固体撮像素子の特性に適 合を図ると同時に, 解像度などカメラ性能の向上を図 るように考慮がなされている.

そこで, ここでは単板式カメラの色多重化方式を中 心に, 現在行われている固体撮像素子を用いたカメラ

\section{正会員 藤 本 真 ${ }^{\dagger}$}

に特有の技術について述べることにする．

\section{2. 単板式カメラの基本構成}

図 1 に単板式カメラの基本構成を示す.被写体像 は, 光学系を介してカラー撮像用の固体撮像素子に結 像され，電気信号に変換される.カラー撮像用素子 は, 分光特性の異なるフィルタが画素毎に配置され， 被写体像の色成分に従った信号がそれぞれの画素から 得られる.この結果, 撮像出力には, フィル夕の並び に従って被写体像の色成分が順次出力され, 色信号の 多重がなされる．固体撮像素子では，読出した信号が どの画素から得られたかを知ることができるので，同 図に示した原色フィルタによる多重化の例のように， 色信号は容易に分離, 復調され, カラーカメラが構成 できる。

このように，固体撮像素子の画素は独立性に優れて

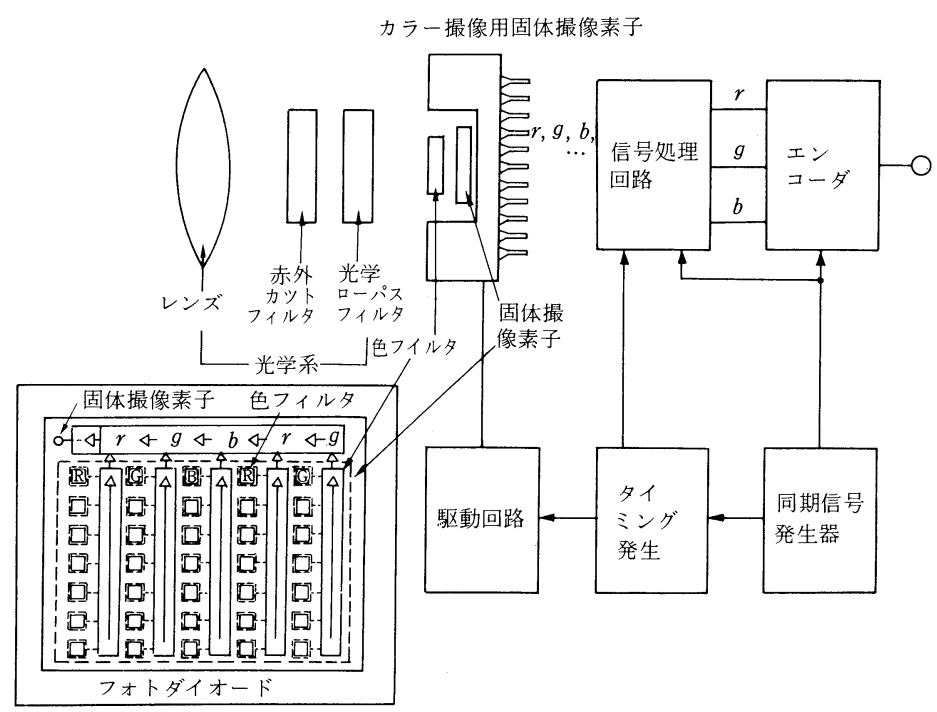

図 1 単板式カメラの基本構成 


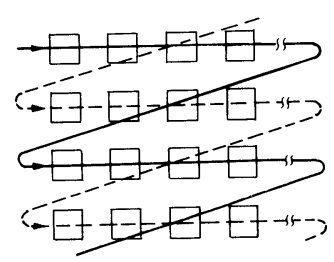

(フレーム蓄積 1 行読出し)

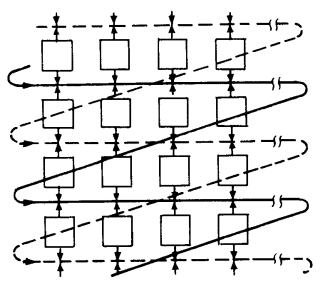

(フィールド蓄積 2 行混合読出し)

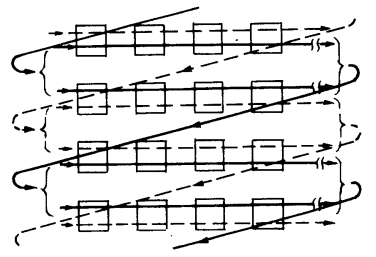

(フィールド蓄積同時 2 行読出し)

図 2 名種読出し方式（実線は, 第 1 のフィールドの読出し, 点線は第 2 の フィールドの読出しを示す)

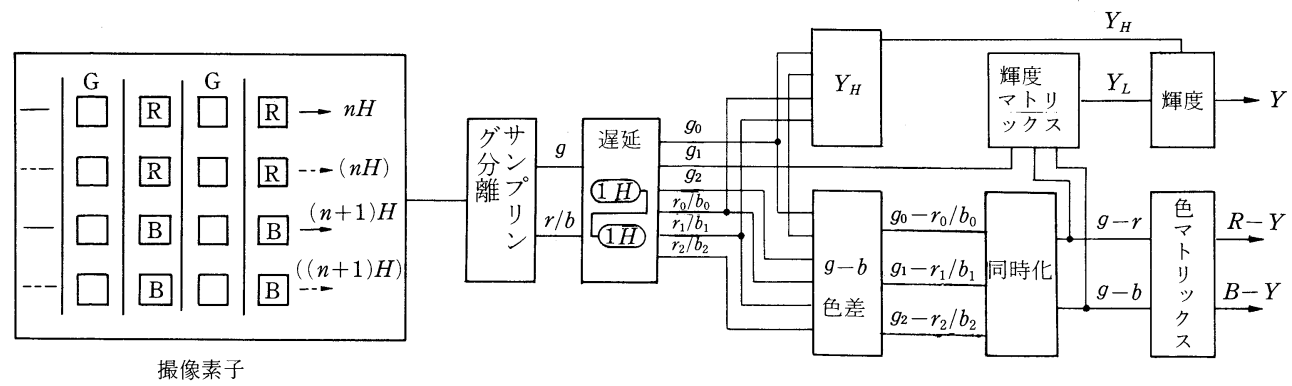

図 $3 \mathrm{G}$ ストライプ $\mathrm{R} / \mathrm{B}$ 線順次方式

いるので, 複雑な色フィル夕の構成すなわち色多重化 が可能であり，後述するように解像度に優れた多くの 方式を可能にしている。しかしこれと同時に, 撮像信 号には，被写体像を空間的に標本化する際の側帯波か らの著しい折り返し成分による偽信号が発生し，画質 を劣化させる，後述するようにこの改善のために，同 図の光学パルスフィルタが投入される.

\section{3. 色多重方式}

\section{1 固体撮像素子の信号読出し方式}

現在実用になっている固体撮像素子には, MOS, インタライン CCD, フレームトランスファ CCD があ る. 色多重化方式は, これらの素子の画素の配置や $S / N$ 特性, 読出し方式に適合して提案されている. この読出し方式は, 図 2 に示すように各画素を走査す る順序のことで，つぎの種類がある．第一は，垂直方 向の各行を順次読出すフレーム蓄積 1 行読出しであ る. 第二は, 先の方式で画素の光蓄積時間が 1 フレー

表 1 最近のカラー撮像用固体撮像素子と色多重化方式

\begin{tabular}{|c|c|c|c|c|c|c|c|c|c|}
\hline \multirow[b]{2}{*}{ 固 } & 素子 構 成 & \multicolumn{8}{|c|}{ インタライン CCD } \\
\hline & 読出し方式 & $\begin{array}{c}\text { フレーム蓄積 } \\
1 \text { 行読出し }\end{array}$ & & \multicolumn{6}{|c|}{ フィールド蓄積 2 行混合読出し } \\
\hline $\begin{array}{l}\text { 摄 } \\
\text { 像 }\end{array}$ & 素 子 名 & $\begin{array}{c}\mathrm{ICXO} 18-\mathrm{K} \\
(ソ ニ ー)\end{array}$ & $\begin{array}{l}\mathrm{LZ22250 \textrm {G }} \\
(\text { シャープ) }\end{array}$ & $\begin{array}{c}\text { MN } 8232 \text { F } \\
\text { (松下) }\end{array}$ & $\begin{array}{c}\text { MN } 3734 \mathrm{~F} \\
\text { (松下) }\end{array}$ & $\begin{array}{c}\text { MN } 8231 \mathrm{~F} \\
\text { (松下) }\end{array}$ & $\begin{array}{c}\mu \mathrm{PD} 3520 \mathrm{D} \\
\quad \text { (日電) }\end{array}$ & $\begin{array}{c}\mu \mathrm{PD} 3514 \\
\quad \text { (日電) }\end{array}$ & $\begin{array}{l}\text { TCD 204 C } \\
\text { (東芝) }\end{array}$ \\
\hline \multirow[t]{2}{*}{$\begin{array}{l}\text { 素 } \\
\text { 子 }\end{array}$} & $\begin{array}{l}\text { 画 素 数 } \\
(\mathrm{H} \times \mathrm{V})\end{array}$ & $510 \times 492$ & $510 \times 490$ & $384 \times 490$ & $422 \times 489$ & $574 \times 499$ & $427 \times 485$ & $384 \times 490$ & $398 \times 492$ \\
\hline & 感光サイズ & $2 / 3^{\prime \prime}$ 相当 & $2 / 3^{\prime \prime}$ 相当 & $\begin{array}{c}\text { スーパー } 8 \\
\text { 相当 }\end{array}$ & $1 / 2^{\prime \prime}$ 相当 & $2 / 3^{\prime \prime}$ 相当 & $1 / 2^{\prime \prime}$ 相当 & $2 / 3^{\prime \prime}$ 相当 & $1 / 2^{\prime \prime}$ 相当 \\
\hline $\begin{array}{l}\text { 色 } \\
\text { 多 }\end{array}$ & 方 式 名 & $\begin{array}{l}\text { G ストライプ } \\
R / B \text { 線順次 }\end{array}$ & 補色方式 & & 色 差 順 & & 完全色 & 順次 & $\mid \begin{array}{l}\text { 周波数 } \\
\text { インタリーブ }\end{array}$ \\
\hline $\begin{array}{l}\text { 重 } \\
\text { 化 } \\
\text { 方 } \\
\text { 式 }\end{array}$ & フィル夕配置 & \begin{tabular}{l|l|l|l|}
$\mathrm{G}$ & $\mathrm{R}$ & $\mathrm{G}$ & $\mathrm{R}$ \\
$\mathrm{G}$ & $\mathrm{R}$ & $\mathrm{G}$ & $\mathrm{R}$ \\
$\mathrm{G}$ & $\mathrm{B}$ & $\mathrm{G}$ & $\mathrm{B}$ \\
$\mathrm{G}$ & $\mathrm{B}$ & $\mathrm{G}$ & $\mathrm{B}$ \\
\end{tabular} & & & 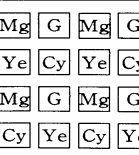 & & \begin{tabular}{|l|l|}
$\mathrm{Mg}$ & $\mathrm{G}$ \\
$\mathrm{Ye}$ & $\mathrm{Cy}$ \\
$\mathrm{Mg}$ & $\mathrm{G}$ \\
$\mathrm{Cy}$ & $\mathrm{Ye}$ \\
\end{tabular} & \begin{tabular}{|l|l|}
$\mathrm{Mg}$ & $\mathrm{G}$ \\
$\mathrm{Ye}$ & $\mathrm{Cy}$ \\
$\mathrm{Mg}$ & $\mathrm{G}$ \\
$\mathrm{Cy}$ & $\mathrm{Ye}$ \\
\end{tabular} & \begin{tabular}{|l|l|l|l|}
$\mathrm{W}$ & $\mathrm{Ye}$ & $\mathrm{W}$ & $\mathrm{Ye}$ \\
$\mathrm{W}$ & $\mathrm{Cy}$ & $\mathrm{W}$ & $\mathrm{Cy}$ \\
$\mathrm{W}$ & $\mathrm{Ye}$ & $\mathrm{W}$ & $\mathrm{Ye}$ \\
$\mathrm{Cy}$ & $\mathrm{W}$ & $\mathrm{Cy}$ & $\mathrm{W}$ \\
\end{tabular} \\
\hline
\end{tabular}


ム時間になるため生じる残像を避けるため素子内部で 垂直方向 2 行を混合して後読出し, 蓄積時間を 1 フィ ールド時間にしたフィールド蓄積 2 行混合読出しであ る. 第三は, 垂直方向 2 行を同時に読出すフィールド 蓄積同時 2 行読出しである.

前の 2 方式はインタライン CCD 型撮像素子に, 後 の方式は MOS 型撮像素子に使われている.フレーム トランスファ CCD の画素の感度分布は構造上フィー ルド間で重盢している．このため読出し方式は実質的 にフィールド蓄積 2 行混合読出しとなる. 読出し方式 の違いは色分離のさい利用できる画素の自由度を決め るため, 色多重化方式にとって重要な要素となる.

\section{2 最近の色多重化方式}

上記の点を考慮して, 最近発表されたカラー用固体 撮像素子と色多重方式を表 1 に示す. 同表を見ると補 色系フィルタが多くみられる. 原色フィル夕は, 白色 光に対し補色フィル夕に比べ透過率が低いため, 高感 度化が重要な要素である単板式カメラは補色系色フィ ル夕による色多重化方式が中心となっている.つぎ に, これらの色多重方式のいくつかを読出し方式毎に 説明する。

（1）フレーム蓄積 1 行読出しの色多重化方式

この読出しの素子に対しては, GストライプR/B 線順次 ${ }^{1)}, \mathrm{G}$ 市松 $\mathrm{R} / \mathrm{B}$ 線順次 ${ }^{23)}$, 色差順次 ${ }^{4)}$ 等, 多 の方式が発表または商品化されているが, ここでは $\mathrm{G}$ ストライプ R/B 線順次方式を説明する.

本方式は, 図 3 に示すように原色のフィル夕を用い る.このため, $\mathrm{G}$ (緑) フィルタを透過した光から得ら れる $g$ 信号は各水平走查で得られるが, $\mathrm{R}$ (赤), $\mathrm{B}$

\begin{tabular}{|c|c|c|c|}
\hline \multirow{2}{*}{\multicolumn{2}{|c|}{$\begin{array}{c}\text { フレームトランスファ } \\
\mathrm{CCD}\end{array}$}} & \multicolumn{2}{|c|}{ MOS } \\
\hline & & (画素補間) & (水平読出し) \\
\hline \multicolumn{2}{|c|}{$\begin{array}{l}\text { フィールド蓄積 } \\
2 \text { 行混合読出し }\end{array}$} & \multicolumn{2}{|c|}{$\begin{array}{l}\text { フィールド蓄積 } \\
\text { 同時 } 2 \text { 行読出し }\end{array}$} \\
\hline $\begin{array}{c}\text { LC } 9921 \\
\text { (三洋) }\end{array}$ & $\begin{array}{c}\text { LC } 9923 \\
\text { (三洋) }\end{array}$ & $\begin{array}{l}\text { HE } 98222 \\
\text { (日立) }\end{array}$ & （日立） \\
\hline $400 \times 504$ & $600 \times 502$ & $384 \times 485$ & $576 \times 486$ \\
\hline $1 / 2^{\prime \prime}$ 相当 & $2 / 3^{\prime \prime}$ 相当 & $2 / 3^{\prime \prime}$ 相当 & $2 / 3^{\prime \prime}$ 相当 \\
\hline $\begin{array}{l}\mathrm{W}, \mathrm{G}, \mathrm{Ye}, \mathrm{Cy} \\
\text { フィルタ }\end{array}$ & & $\begin{array}{l}\mathrm{W}, \mathrm{Cy}, \mathrm{Ye} \\
\text { デル夕配置 }\end{array}$ & W, Cy, Ye, G \\
\hline $\mathrm{Ye} \mathrm{Cy}$ & e $C y$ & \begin{tabular}{|lll}
$\mathrm{W}$ & $\mathrm{Cy}$ & $\mathrm{Y}$ \\
\end{tabular} & 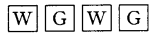 \\
\hline $\mathrm{G} \mathrm{W}$ & $\mathrm{w}$ & ] $\mathrm{Ye} \mathrm{W} \mathrm{Cy}[$ & $\mathrm{Cy} \widehat{\mathrm{Ye}} \mathrm{Cy}$ \\
\hline $\mathrm{Cy} \mathrm{Ye}$ & $\mathrm{ye}$ & \begin{tabular}{|lll}
$\mathrm{W}$ & $\mathrm{Ye}$ & $\mathrm{W}$ \\
\end{tabular} & $\mathrm{W} \mathrm{G} \mathrm{W}, \mathrm{G}$ \\
\hline $\mathrm{G}, \mathrm{W}$ & $\mathrm{w}$ & ] $\mathrm{Ye} \mathrm{W}, \mathrm{Cy}[$ & $\mathrm{Cy} \mathrm{Ye} \mathrm{Cy} \mathrm{Ye}$ \\
\hline
\end{tabular}

(青) フィルタを介した光から得られる $r$ と $b$ 信号は 水平走查ごとに順次出力される。そこで, $r$ または $b$ が欠けた走査列では, その前後の走査で得られた信 号から内插して欠けた $r$ または $b$ 信号を得る同時化 処理を行い, 得られた $r, g, b$ 信号よりエンコーダ を介して複合カラー信号とされる。

しかし, 各色信号のサンプリング数や位相が異なっ ているため, これをエンコードしたのでは色差信号に 偽信号が発生する. 実際の処理では図 3 の信号処理回 路の概要に示すように, 各走查で得られるサンプリン グ位相の等しい $g$ と $r$ または $b$ 信号から，いったん $g-r$ または $g-b$ 色差信号を作り, これを同時化し て色差信号を得て偽信号の発生を防いでいる。また， 輝度信号は各走查で得られた $g$ 信号と同時化して補 間された $g-r$ と $g-b$ 色差信号から作られる. しか し, こうして得られた輝度信号は $g$ 信号に代表され, 水平のサンプリング数は画素数の半分になる. そこ で, 2 水平走査の信号を加算して輝度の高域成分と し, 先の輝度信号を低域成分として最終的な輝度信号 を得ている。

（2）フィールド蓄積 2 行混合読出しの色多重化方 式

この読出しに対する色多重化方式は, 垂直方向 2 画 素の信号を混合するため, 混合された信号に色信号が 順次多重されるようなフィル夕構成にしなければなら ない. 色差順次 ${ }^{4) 5}$, 完全色差順次 ${ }^{6)}$, 周波数インタリ ーブ7)やフレームトランスファ $\mathrm{CCD}^{8) 9}$ に用いられる 白 $(\mathrm{W})$, 緑 $(\mathrm{G})$, イエロー $(\mathrm{Ye})$, シアン $(\mathrm{Cy})$ フィ ル夕の方式は，これを考慮した方式である.色差順次 方式を用いてこれを説明する。

色差順次方式の色フィルタは, $\mathrm{Mg}$ (マゼン夕), G, $\mathrm{Ye}, \mathrm{Cy}$ の 4 色を図 4 のように構成して用いる。この 結果, 各色フィルタを介した光は $m g, g, y e, c y$ 信 号として各画素で光電変換され, 読出された出力信号 は図 5 に示すスペクトルを持つ. $m g$ と $c y$ または $g$ とyeが混合して読出される走查列と $m g$ と ye また は $g$ と $c y$ が混合して読出される走査列の出力信号 は, 低域成分として $m g+g+y e+c y=2 r+3 g+2 b$ の信号成分を持ち, 水平のサンプリング周波数の $1 / 2$ の点に $m g+c y-g-y e=2 r-g$ 信号成分と $m g+y e$ $-g-c y=2 b-g$ 信号成分が色信号として水平走査毎 に多重されている。この場合も $\mathrm{R} / \mathrm{B}$ 線順次と同様に $2 つ$ 色差信号 $2 r-g$ と $2 b-g$ は水平走查毎に順次 得られる。そこで同様に同時化処理を行って，2つの 色差信号と低域信号から複合カラー信号を合成する. この方式の場合, 各水平走査での信号の低域成分が等 


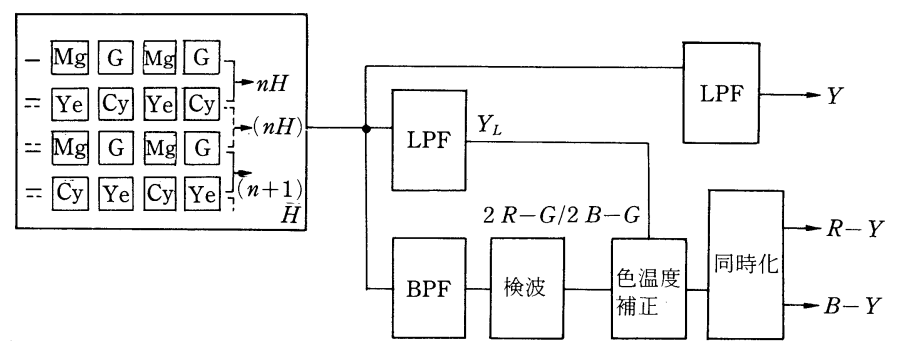

図 4 色差順次方式

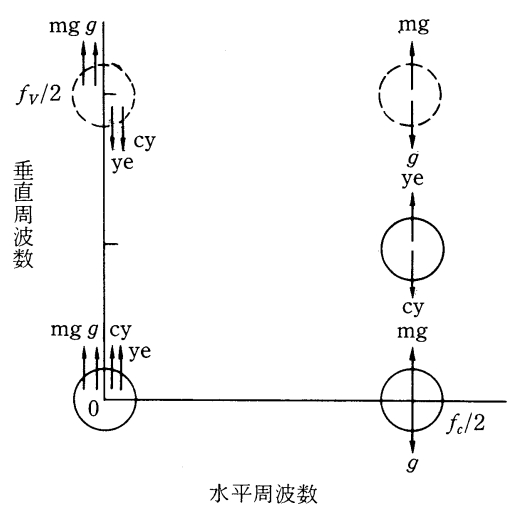

図 5 色差順次方式の 2 次元スペクトル



図 $6 \mathrm{~W}, \mathrm{G}, \mathrm{Ye}, \mathrm{Cy}$ フィル夕による方式
しいので，この低域成分を直接輝度信号とすることで 信号処理が簡単な構成で行われる. 信号処理回路の基 本構成を図 4 に示す.

（3）フィールド蓄積同時 2 行読出しの色多重化方 式

垂直方向の 2 行を同時に読出すこの方式は, 構造上 画素の読出しが比較的自由に行えるMOS 型について のみ行われている. 本方式は空間的に最短の位置に異 なるフィル夕繰り返しを設定できるため解像度的に有 利な色多重方式が可能である.色多重方式には，W， $\mathrm{Cy}, \mathrm{Ye}$ フィル夕を同時に読出される 2 水平列で各フ イルタがインタリーブするように配列した方式 ${ }^{10)}$, $\mathrm{W}, \mathrm{Cy}, \mathrm{Ye}$ のデルタ配置による方式 ${ }^{11}, \mathrm{~W}, \mathrm{G}$,

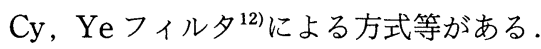

図6にW, G, Cy, Yeフィルタの色フィル夕配置 1076 (22)
と処理の基本構成を示す.この例では, 各走査で $\mathrm{W}$, $\mathrm{G}, \mathrm{Cy}, \mathrm{Ye}$ フィルタを介した画素の信号 $w, g, c y$, yeがすべて得られる.これより $(w-c y)+(y e-g)=$ $2 r,(w-y e)+(c y-g)=2 b, \mathrm{Ye}+\mathrm{Cy}-\mathrm{W}+3 g=4 g$ として各原色信号を得, これをエンコーダを介して複 合カラー信号とするのがこの方式である.

\section{4. 偽信 号}

\section{1 光学ローパスフィルタ}

被写体に含まれる空間的な周波数成分の制限なしで 撮像した場合, 多重された色信号に被写体像の高周波 成分が混入する, あるいは, 画素により標本化される さいに発生する折り返し成分が基底帯域に混入するた めに, クロスカラーや折り返しひずみ等の偽信号を発 生し, 画質を劣化させる.そこで, 被写体の持つ空間 的な周波数成分を光学的に制限するために光学ローパ スフィルタが用いられる。この方法については，Gス トライプ $\mathrm{R} / \mathrm{B}$ 線順次方式に対する詳しい報告 ${ }^{13)}$ があ るので，同方式を例に説明にする.

図 7 は, $\mathrm{G}$ ストライプ R/B 線順次方式の 2 次元ス ペクトラムである。印は側帯波のキャリヤの位置を

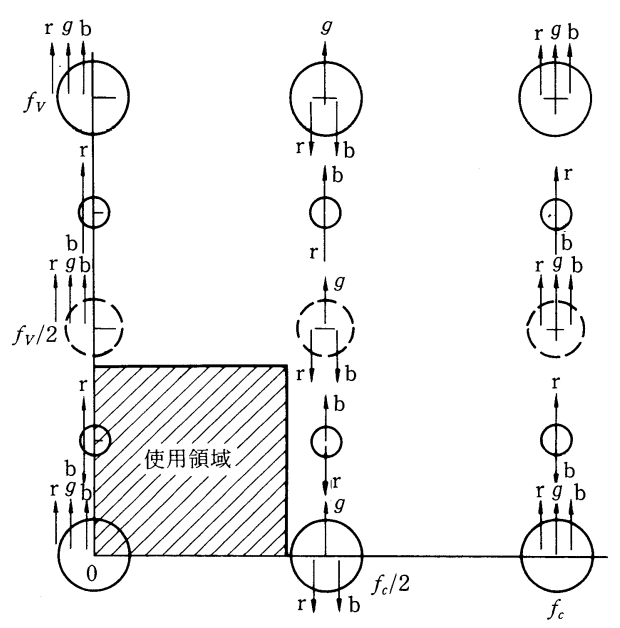

図 $7 \mathrm{G}$ ストライプ R/B 線順次のスペクトル テレビジョン学会誌 Vol. 40, No.11 (1986) 


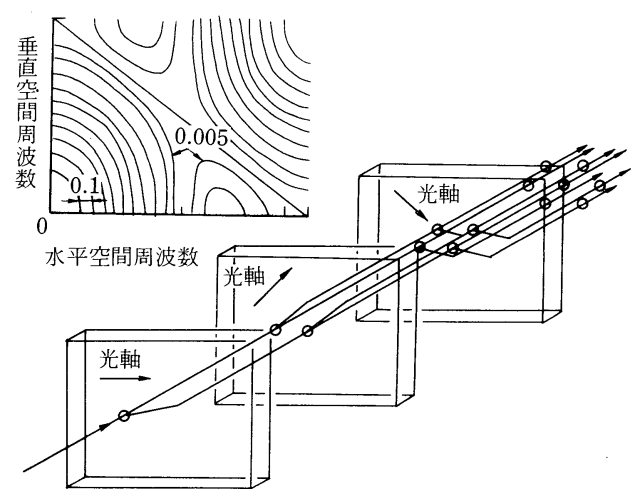

図 8 水晶フィルタの構成とレスポンスの例

示している．側帯波からの折り返しをなくすには，こ れらのキャリヤ位置での被写体像の周波数成分をなく さなければならない.そこで水晶フィルタのトラップ 周波数をキャリヤ位置に設定して用いる.このために は, 2 次元のフィル夕が必要となり, 図 8 に示すよう に 3 枚の水晶フィルタを重ねてこれを実現している.

これと同様な構成の光学ローパスフィルタを色差順



\section{2 信号処理}

上述のようにキャリヤの生じる点は広く分布し,す べての点で制限することは難しい。 また, 著しい帯域 制限はそれ自体解像度の低下を意味し好ましくない. そこで光学的に制限することを最小限に止め信号処理 での軽減が図られている，つぎにこの例を説明する。

色差順次方式では異なる 2 つ色信号が水平走査毎 に順次出力される.このため各色信号の標本化位置は 垂直方向にインタリーブして, 各信号の側帯波は逆相 となっている.この結果, 垂直方向の面素間で色分離 を行う, すなわち減算を行うと, 先の側帯波成分が加 算されてしまう。そこで, 図 4 の処理回路に示したよ うに, 各水平走查で得られる信号から 1 つの色差信号 を直接得た後同時化し 2 つ色差信号とする処理が行 われる。こうすると, 色差信号を作る各色信号の側帯 波の垂直成分の方向は一致しているため, 少なくとも 輝度成分が色差信号には混入しない. このような処理 は, 各水平走査で得られる信号から直接 1 つの色差信 号が得られる方式では共通に可能であり，Gストライ プ R/B 線順次方式も同様の処理がなされている.

また, 先の $\mathrm{W}, \mathrm{G}, \mathrm{Cy}, \mathrm{Ye}$ フィルタによる方式で は, 信号処理過程で得られる信号に含まれる側帯波か らの折り返し成分の位相関係を積極的に利用した処理 が示されている12.

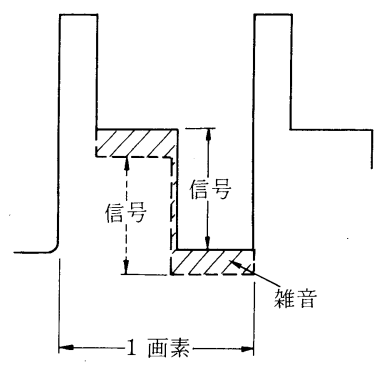

図 $9 \mathrm{CCD}$ の出力信号とスイッチング雑音

\section{5. $S / N$ 改 善}

固体撮像素子の雑音発生機構は素子構造によって異 なり, 一概にはいえない。この中には, 発生機構から 除去可能な雑音もあり,これに対しては改善処理がな される．この代表に CCD 型固体撮像素子に使われる 相関二重サンプリング15)がある.

$\mathrm{CCD}$ 型固体撮像素子の雑音は, 主に光ショット雑 音と出力部のリセット雑音およびアンプの $1 / f$ 雑音 である.このうち光ショット雑音は入射光のゆらぎに よるから,これを除去する方法はない.一方, リセッ 卜雑音は図 9 に示すように, リセットに伴う雑音と信 号を別に取り出せるので, 各信号をサンプリングして 減算することで除去できる．この処理が相関二重サン プリングであり, 通常, CCD 型の固体撮像素子を用 いる場合, 素子出力は相関二重サンプリング処理の 後, 信号処理回路に送られる.

信号処理回路における固体カメラ固有の雑音低減の 方法は特にない。一般的に行われるクリスプニングや 巡回型のコムフィルタや低彩度, 低輝度での色信号の 抑制などの画質改善処理は, 必要に応じて撮像管方式 のカメラで行われたのと同様な処理が施される.しか し基本的には, 上述の素子出力時の雑音対策が中心と なる。

\section{6. 固体撮像素子に特有な現象}

固体撮像素子に特有な現象にはブルーミング，スミ ア, 素子欠陥等がある。

特にスミアは画質を著しく劣化させるため, これを 垂直ブランキング期間に記録して, 記録した信号でス ミア成分を補正する回路を用いることも行われた。し かし, 最近の固体撮像素子では, この性能は大きく改 善され，実用上問題のない程度になってきている．

一方, 素子久陥の補正は, 素子の生産性面から有効 で, あらかじめ欠陷のある画素の位置を記憶してお き, この画素を前置補間して用いる.ただし, カラー 


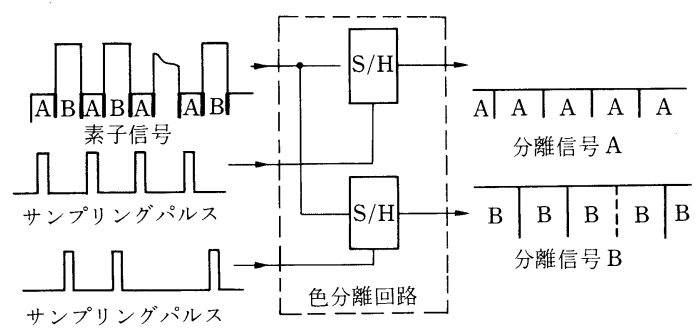

図 10 カラー撮像素子の欠陥補正

用撮像素子の場合, 同色のフィルタを配した画素と置 き換えるために，色信号を分離する回路で，各色分離 のためのサンプリングを停止して，置き換えを行う． この例を図 10 に示す.

固体撮像素子の開口率は 30〜 50\%ほどあるが, 残 りはスミアの発生を避けるためアルミで遮光されてい る.この結果, 素子表面の反射率は高く, フレアが発 生しやすい.フレア防止板を付けて, この対策を行う ものもある ${ }^{13)}$.

\section{7. むす び}

ビデオカメラの諸性能は, 感度, 解像度, 色再現性 等, 多くの要素からなっている. 固体撮像素子を用い たカメラにおいても, 色フィルタの分光特性をはじめ とする光学系や， $\gamma$ 補正や色再現改善のためのマトリ ックス回路をはじめとする信号処理系に，これら諸特 性を考慮した処置がなされている。しかし，これらの 方法はカメラ共通の技術であり, 固体カメラに固有と
いえるものはない．そこで，ここでは固体撮像素子を 用いたカメラ特有の多重化方式とこれに伴う偽信号の 処理を中心にカメラの基本技術について述べた.

(昭和 61 年 7 月 2 日受付)

\section{【参 考 文 献〕}

1）増田ほか：“ハンディカム CCD-M 8”, テレビ学技報, TEBS 107-3(Feb., 1985)

2）濱田ほか：“緑市松線順次方式単板カラーカメラ”,テレビ学 技報, TEBS 87-7(May, 1983)

3）西村ほか：“CCD R/B 線順次カラーカメラの LSI 化”, テレ ビ学技報, $\operatorname{ED~} 770$ (Feb., 1984)

4）森村ほか：“改良形色差順次単板カラー方式”,テレビ学技報, TEBS 87-6(May, 1983)

5）曽根ほか：“フィールド読み出し方式 CCD のカラー撮像評 価”, テレビ学技報, TEBS 87-3(May, 1983)

6）河野ほか：“完全色差順次単板カラー化方式”,テレビ学技報, ED 836(Feb., 1985)

7) 大井ほか：“新周波数インタリーブ CCD カメラ”,テレビ学 技報, ED 837 (Feb., 1985)

8）藤本ほか：“単板カラー化方式”，テレビ学技報，TEBS 643(Aug., 1980)

9）箕谷ほか：“1/2 単板カラーFTCCD”, テレビ学技報, ED 846 (Feb., 1985)

10）増田ほか: “MOS 単板カラーカメラ”, テレビ学技報, TEBS 69-1(Feb., 1981)

11）増田ほか：“PAL 方式 MOS 単板カラーカメラ”，テレビ誌, 37,10 , pp. 840-846(Oct., 1983)

12）今出ほか: “水平転送 MOS 形カメラのカラー化方式の検 討”, テレビ学技報, ED 938(Feb., 1986)

13）小川ほか: “カラーカメラ用 CCD 撮像ブロック”, テレビ学 技報, ED 844 (Feb., 1985)

14）峰間ほか：“VHS ビデオムービーGR-C 7 の開発”, テレビ 学技報, TEBS 110-4 (May, 1986)

15） Sequin, Tompsett, 武石, 香山監訳 : “電荷転送ディバイス”, 近代科学社, pp. 107-114 